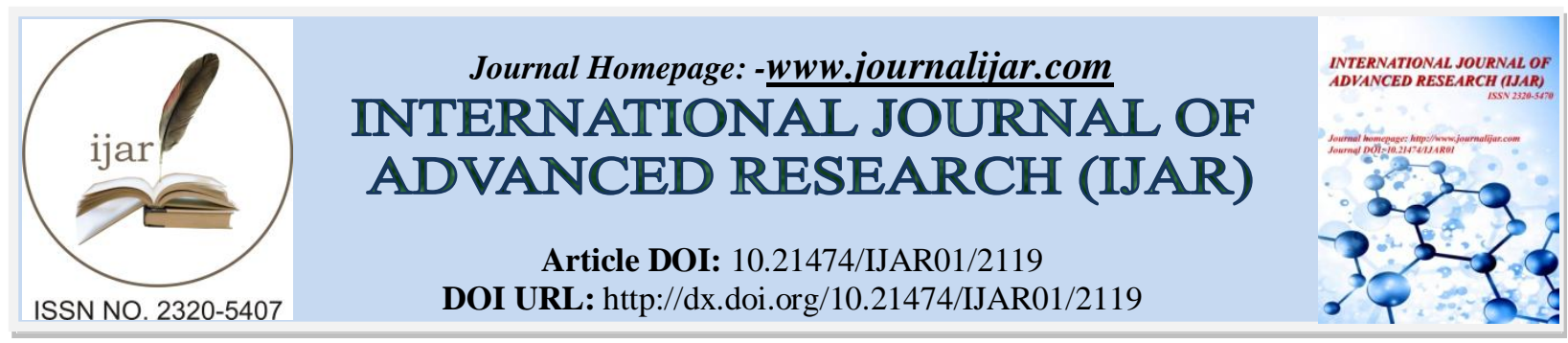

RESEARCH ARTICLE

\title{
BIOCHEMICAL EVALUATION OF "Spinaciaoleracea" L. (SPINACH).
}

\author{
Y. D. Nikam ${ }^{1}$, P. P. Ahire ${ }^{2}$, V. B. Kadam ${ }^{3}$ and K. A. Mahamane' ${ }^{3}$.
}

Department of Botany \& Research Centre, K.T.H.M. College, Nashik-422002.

\section{Manuscript Info}

Manuscript History

Received: 25 September 2016

Final Accepted: 27 October 2016

Published: November 2016

Key words:-

Spinaciaoleracea, carbohydrates, fats, seasons.

\begin{abstract}
Through biochemical compositions we can study many important nutritional aspects essential for human body. The study was held to determine the seasonal variation of fats and carbohydrates from leaf, stem and root of Spinaciaoleracea L. which is one of the most enrich vegetable used all over the world by people. Comparative account of carbohydrate in summer was higher compared to winter and monsoon but at the same time it was highest in stem during summer and highest in root during winter and monsoon. Fats content were high during summer compared to winter and monsoon, but roots showed high concentration of fats compared to stem and leaves.
\end{abstract}

Copy Right, IJAR, 2016,. All rights reserved.

\section{Introduction:-}

S. oleracea, commonly called spinach, was long considered to be belonging to the family Chenopodiaceous, but in 2003, that family was integrated into the family Amaranthaceae in the order Caryophyllales. Spinach belongs to subfamily Chenopodioideae in family Amaranthaceae. Variation is observed in the older and more modern varieties of the spinach plant. During warm conditions older varieties are more liable to bolt early. Newer varieties tend to grow more rapidly, but have less of an incline to run up to seed. The older species tend to have a stronger and bitterer taste and narrower leaves. Broader leaves and round seeds are mostly observed in the new varieties.

In the ranking list for nutrient richness, among the World's Healthiest vegetables, Spinach tops the chart. Not just rich in vitamins and minerals, but is also concentrated in health-promoting phytonutrients like the carotenoids (betacarotene, zeaxanthin, and lutein) and flavonoids which produce the powerful antioxidant protection. Spinach is of much importance to skin, bone, hair as it provides proteins, minerals, iron and vitamins to us. It acts as a major precaution for blood glucose control in diabetics, low blood pressure, cancer risk, weak bones, asthma and many more.

Variation is observed in the older and more modern varieties of the spinach plant(Barzegar M, Erfani F, Jabbari A, Hassandokit MR, 2007). During warm conditions older varieties are more liable to bolt early. Newer varieties tend to grow more rapidly, but have less of an incline to run up to seed. The older species tend to have a stronger and bitterer taste and narrower leaves. Broader leaves and round seeds are mostly observed in the new varieties.

The research work regarding the chemical processes within or relating to living organisms is said to be biochemistry, also known as biological chemistry. The complication of life can occur during biochemical process, if we control the information flow through biochemical signaling and through metabolism chemical energy flow. Various study fields like botany, medicines, genetics, etc. (Voet 2005). which are areas of life science, are engrossed in research related to biochemical because biochemistry has made it easy to understand the living processes, this 
made biochemistry more successful since last few decades of the $20^{\text {th }}$ century. Now-a-days, studying and understanding the biological molecular processes that takes place within a living cell is greatly to the whole organisms due to the main focus on pure biochemistry.

\section{Materials And Methods:-}

The required species of Spinach was collected from the local market and was used for preparing the dry powder. Before sun drying it was separated into leaf, stem \& root. The fresh material was used for chlorophyll estimation. The remaining was dried $\&$ converted into powder form. This particular procedure was carried out in seasonal format i.e., summer, monsoon \& winter respectively.

\section{Quantitative estimation of total Carbohydrate:}

Carbohydrates were estimated by methods suggested by McGready (1950), and Nelson (1941).

Reagents:-

- Somogy's reagent (4 gm. $\mathrm{CuSO}_{4}+24$ gm. anhydrous $\mathrm{Na}_{2} \mathrm{CO}_{3}+16$ gm. Na-K tartarate (Rocheette salt) $+180 \mathrm{gm}$ Anhydrous $\mathrm{Na}_{2} \mathrm{SO}_{4}$.

- Nelson aresenomolybdate reagent :- $\left(24 \mathrm{gm}\left(\mathrm{NH}_{4}\right) 6 \mathrm{MO}_{7} \mathrm{O}_{24}, 4 \mathrm{H}_{2} \mathrm{O}\right.$ Ammonium molybdate $)+\left(3 \mathrm{gm} \mathrm{Na}_{2} \mathrm{SO}_{4}, 7 \mathrm{H}_{2} \mathrm{O}\right)$.

- Both solutions were mixed and incubated at $37^{\circ} \mathrm{C}$ for 24 hours before use and they were stored in brown bottle.

- Standard sugar solution was prepared by dissolving $10 \mathrm{mg}$ glucose in $100 \mathrm{ml}$ distilled water.

Procedure:-

1. $1 \mathrm{gm}$. of sample was crushed with $10 \mathrm{ml} 80 \%$ ethanol in mortar and pestle by adding acid free sand, and then filtered through Wathman filter paper. The filter and residue were collected separately.

2. The alcohol residue was taken in $250 \mathrm{ml}$ in conical flask. $150 \mathrm{ml}$ distilled water and $5 \mathrm{ml}$ conc. HCL were added in it. Hydrolysed for 30 minutes and cooled to room temperature. $\mathrm{Na}_{2} \mathrm{Co}_{3}$ was added bit-by bit until the extract became neutral $(\mathrm{pH}=7)$. The extract was filtered. Residue was discarded .Total volume of filtered was served as a sample for starch. First filtrate was taken in conical flask and condensed on water bath up to 2-3 minutes then distilled water was added to the filtrate, and then filtered, after mixing residue was discarded and the volume of filtrate was served for reducing sugar.

3. $20 \mathrm{ml}$ of this filtrate was taken in $150 \mathrm{ml}$ conical flask, $2 \mathrm{ml}$ of conical flask; $2 \mathrm{ml}$ of conc. $\mathrm{HCl}$ was added to it and corked. It was then hydrolysed for 30 minutes and cooled at room temperature. $\mathrm{Na}_{2} \mathrm{CO}_{3}$ was added bit-by -bit until the extract became neutral $(\mathrm{pH}=7)$. Then this extract filtered and residue discarded. The final volume of the filtrate was measured. It was served as a sample for total sugar.

4. $0.5 \mathrm{ml}$ of aliquot sample was taken in each test tube and $1 \mathrm{ml}$ of Somogy's reagent was added in it. All test tubes were placed in boiling water bath for 30 minutes, cooled the tubes to room temperature and $1 \mathrm{ml}$ of aresenomolybdate reagent which is poisonous was added to it. The content was mixed thoroughly. Then the content was diluted to a volume of $10 \mathrm{ml}$ and its absorbance measured $\mathrm{OD}$ at $560 \mathrm{~nm}$ in spectrophotometer.

\section{Estimation of fats:-}

A small quantity of free acids is usually present in oils along with the triglycerides (Cox H.E. and Pearson. D, 1962). The free fatty acid content is known as acid number/acid value. It increases during storage. The keeping quality of oil therefore relies upon the free fatty acid content.

Reagents:-

- $1 \%$ phenolphthalein in $95 \%$ ethanol

- $\quad 0.1 \mathrm{~N}$ potassium hydroxide

- Neutral solvent: Mix $25 \mathrm{ml} 95 \%$ alcohol and $1 \mathrm{ml}$ of $1 \%$ phenolphthalein solution and neutralize with N/10 alkali.

\section{Procedure:-}

Dissolve $1-10 \mathrm{~g}$ of oil or melted fat in $50 \mathrm{ml}$ of the neutral solvent in a $250 \mathrm{ml}$ conical flask. Add a few drops of phenolphthalein. Titrate the content against $0.1 \mathrm{~N}$ potassium hydroxide. Shake constantly until pink colour which persists for fifteen seconds is obtained.

\section{Result And Discussion:-}

\section{Total Carbohydrates:-}

The total carbohydrate content of leaves, stem \& root were usually higher in summer as compared to winter and monsoon. 
The range of total carbohydrate content of leaves was $3.75 \mathrm{mg} / \mathrm{g}$ dry wt. to $3.49 \mathrm{mg} / \mathrm{g}$ dry wt. where in summer accumulation of total carbohydrates was $(3.75 \mathrm{mg} / \mathrm{g})$ than in winter $(3.66 \mathrm{mg} / \mathrm{g})$ and in monsoon it was found lowest (3.49 mg/g).

Where as in stem it ranged from $6.13 \mathrm{mg} / \mathrm{g}$ to $3.55 \mathrm{mg} / \mathrm{g}$ dry wt., in Monsoon it was recorded lowest (3.55 mg/g) \& highest in summer $(6.13 \mathrm{mg} / \mathrm{g})$ whereas modest in winter $(4.37 \mathrm{mg} / \mathrm{g})$.

The range of total carbohydrate in root was ranged from $6.06 \mathrm{mg} / \mathrm{g}$ to $4.67 \mathrm{mg} / \mathrm{g}$ dry wt., in summer it was highest (6.06 $\mathrm{mg} / \mathrm{g})$ compared to monsoon $(4.67 \mathrm{mg} / \mathrm{g})$ \& winter $(5.06 \mathrm{mg} / \mathrm{g})$. The comparison can be studied in the following table-1 below.

Fats:-

The fats content of leaves was found in the range of 0.033 to $0.01 \mathrm{mg} / \mathrm{g}$ dry wt., in summer it was highest $(0.033 \mathrm{mg} / \mathrm{g})$ compared to winter $(0.015 \mathrm{mg} / \mathrm{g})$ and monsoon $(0.010 \mathrm{mg} / \mathrm{g})$.

Where as in stem it ranged from 0.014 to $0.005 \mathrm{mg} / \mathrm{g}$ dry wt. in monsoon it was lowest $(0.005 \mathrm{mg} / \mathrm{g})$, in winter was modest $(0.011 \mathrm{mg} / \mathrm{g}) \&$ in summer was highest $(0.014 \mathrm{mg} / \mathrm{g})$

The concentration of fats was highest in root as compared to leaf \& stem. It ranged from 0.038 to $0.009 \mathrm{mg} / \mathrm{g}$ dry wt., in summer it was highest $(0.038 \mathrm{mg} / \mathrm{g})$, in winter it was modest $(0.028 \mathrm{mg} / \mathrm{g}) \&$ in monsoon was lowest $(0.009$ $\mathrm{mg} / \mathrm{g}$ ). The comparison can be studied in following table no. 2 .

\section{Conclusion:-}

Carbohydrates can be observed from table no. 1 and seen that their production was high in summer, to be precise in the stem region during summer and in root region during winter and monsoon. Fats content observed in table no. 2 was high in summer in the root region while in monsoon and winter it was high in leaf region. This result indicates that the particular season shows high amount which is beneficial for that particular product harvesting.

Table No.1: Seasonal variation in total carbohydrate.

\begin{tabular}{|c|c|c|c|c|}
\hline \multirow[t]{2}{*}{ Sr. No } & \multirow[t]{2}{*}{ Plant Part } & \multicolumn{3}{|c|}{$\begin{array}{l}\text { Seasons (Total Carbohydrate) } \\
\text { (Mg/g dry wt.) }\end{array}$} \\
\hline & & Summer & Monsoon & Winter \\
\hline 1 & Leaf & 3.75 & 3.49 & 3.66 \\
\hline 2 & Stem & 6.13 & 3.55 & 4.37 \\
\hline 3 & Root & 6.06 & 4.67 & 5.06 \\
\hline
\end{tabular}

Table No. 2: Seasonal variation in fats.

\begin{tabular}{|l|l|l|l|l|}
\hline \multirow{2}{*}{ Sr. No } & \multirow{3}{*}{ Plant Part } & $\begin{array}{l}\text { Seasons (Fats) } \\
\text { (Mg/g dry wt.) }\end{array}$ & \multicolumn{2}{|l|}{} \\
\cline { 3 - 5 } & & Summer & Monsoon & Winter \\
\hline 1 & Leaf & 0.03 & 0.01 & 0.015 \\
\hline 2 & Stem & 0.014 & 0.005 & 0.011 \\
\hline 3 & Root & 0.038 & 0.009 & 0.028 \\
\hline
\end{tabular}

\section{References:-}

1. Barzegar M, Erfani F, Jabbari A, Hassandokit MR (2007) Chemical composition of 15 spinach (Spinaceaoleracea L.) cultivars grown in Iran. Ital J Food Sci 19: 309- 318.

2. Balogun A.M. and Fetuga B.L. 1958. Fatty acid composition of seed oils of some members of the Leguminous family. Food Chemistry. 17:175-182.

3. Cox H. E. and Pearson, D. (1962): The chemical analysis of foods Chemical publishing Co Inc New York p 420 .

4. Boswell Victor R. Garden Peas and Spinach from the Middle East. 1949. National Geographic Magazine, $96: 2$

5. He T, Huang CY, Chen H, Hou YH. Effects of spinach powder fat-soluble extract on proliferation of human gastric adenocarcinoma cells. Biomed Environ Sci 1999; 12: 247-252. 
6. Hochmuth GH, Varrina CS, Stall WM, Kucharek TA (2003). Spinach production in Florida. University of Florida. IFAS Ext., 37:247-249

7. Kadam V. B., K. R. Khandare, and Sunanda Salve, (2014): "Biochemical evaluation of some medicinal plants of Genus Terminalia (Combretaceae) of Marathwada region in Maharashtra" IJRPLS, 2014, 2(2): 213-217.

8. LeStrangeM.,KoikeS.,ValenciaJ.,ChaneyW.Spinach production in California.Vegetable Research and Information Center.

9. McGready, R.H.Goggot, J.Silvera and Owens H.S., Determination of starch and amylase in vegetables application to peas, Anal. Chem. (1950), 22: 1156-1158.

10. Nelson N., A photometric adapt ion of the somogyi method for the determination of glucose. J. Biol. Chem. (1941), 153: 375-380.

11. Voet, D; Voet, JG (2005). Biochemistry (3th ed.). Hoboken, NJ: John Wiley \& Sons Inc.ISBN 9780471193500. Archived from the original on September 11, 2007. 